\title{
Allozyme diversity in slugs of the Carinarion complex (Mollusca, Pulmonata)
}

\author{
THIERRY BACKELJAU*, LUC DE BRUYN†, HANS DE WOLF†, KURT JORDAENS $\dagger$, \\ STEFAN VAN DONGEN $\$$ \& BIRGITTA WINNEPENNINCKX§ \\ Malacology Section, Royal Belgian Institute of Natural Sciences, Vautierstraat 29, B-1000 Brussels, †Department of \\ Biology, University of Antwerp (RUCA), Groenenborgerlaan 171, B-2020 Antwerp and $\ddagger$ Department of Biology \& \\ $\S$ Department of Biochemistry, University of Antwerp (UIA), Universiteitsplein 1, B-2610 Wilrijk, Belgium
}

\begin{abstract}
Previous allozyme analyses of the hermaphroditic terrestrial slugs Arion fasciatus, A. circumscriptus and $A$. silvaticus (subgenus Carinarion) have suggested that in North America these species are each single monomorphic strains. However, new data on 18 putative enzyme loci show that in western Europe the three taxa, respectively, consist of at least three, two and 12 homozygous multilocus genotypes (strains), which regularly co-occur. The current opinion that American and European Carinarion populations are similarly structured, and that colonization events did not affect the population genetics of North American Carinarion, should therefore be readdressed. The present data also provide the first indication of heterozygosity and possible outcrossing in Carinarion. Nevertheless, uniparental reproduction is confirmed as the main breeding system in West European Carinarion, although the high incidence of multistrain populations in $A$. silvaticus and $A$. fasciatus appears at variance with the current model of population genetic structuring in selfing terrestrial pulmonates. Finally, the systematic status of the three Carinarion spp. is tentatively questioned.
\end{abstract}

Keywords: allozymes, hermaphroditic slugs, homozygous strains, population genetics, uniparental reproduction.

\section{Introduction}

Arion fasciatus (Nilsson, 1823), A. circumscriptus Johnston, 1828 and A. silvaticus Lohmander, 1937 are morphologically highly similar, hermaphroditic terrestrial slug species, which belong to the arionid subgenus Carinarion Hesse, 1926. The three species are widely distributed in Europe and North America (Chichester \& Getz, 1969; Kerney et al., 1983) and their population genetics has been dealt with in two major allozyme surveys. McCracken \& Selander (1980) reported that in North America each species consists of a single homozygous strain, whereas in Ireland Foltz et al. (1982) observed one homozygous strain of $A$. circumscriptus and two of $A$. silvaticus. These data were interpreted as suggesting that: (i) Carinarion spp. are selfers; (ii) the single strain structure of American populations is not the result of a loss of genetic variation (e.g. founder effects) caused by their introduction from more variable European populations (Selander \& Ochman, 1983;

*Correspondence. E-mail: tbackeljau@kbinirsnb.be
Foltz et al., 1984); and (iii) the three taxa involved deserve species rank because of their low mean genetic identities, respectively $I=0.65$ between the three species (McCracken \& Selander, 1980) and $I=0.74$ between $A$. circumscriptus and $A$. silvaticus (Foltz et al., 1982).

However, Foltz et al. (1982) did not consider $A$. fasciatus (which was the most intensively studied species in North America) and did not investigate continental populations of both other species. Hence, to assess whether the studies of McCracken \& Selander (1980) and Foltz et al. (1982) were sufficiently representative for Carinarion as a whole, we extended the survey by including European $A$. fasciatus and by screening the two other species in the European mainland.

\section{Materials and methods}

Vertical polyacrylamide gel electrophoresis (PAGE) was used to screen 16 enzymes in $53 \mathrm{~A}$. fasciatus, 71 $A$. circumscriptus and $115 \mathrm{~A}$. silvaticus (Table 1). Species identifications were based on Lohmander 
Table 1 Origins, numbers of specimens and numbers of strains (in parentheses) of Arion fasciatus (fasc.), A. silvaticus (silv.) and A. circumscriptus (circ.) sampled for this study

\begin{tabular}{|c|c|c|c|c|}
\hline Locality & fasc. & silv. & circ. & Total \\
\hline \multicolumn{5}{|l|}{ Austria } \\
\hline Rottenegg & $1(1)$ & $1(1)$ & - & $2(2)$ \\
\hline \multicolumn{5}{|l|}{ Belgium } \\
\hline Antwerpen, 't Half Maantje & - & $12(3)$ & $14(2)$ & $26(5)$ \\
\hline Antwerpen, Hobokense Polder & - & $4(4)$ & - & $4(4)$ \\
\hline Antwerpen, RUCA campus & - & $14(1)$ & - & $14(1)$ \\
\hline Antwerpen, RUCA Plein & - & $6(2)$ & $3(1)$ & $9(3)$ \\
\hline Balen & - & $17(2)$ & - & $17(2)$ \\
\hline Dinant, Bouvignes & - & $1(1)$ & $3(1)$ & $4(2)$ \\
\hline Dourbes & - & - & $2(1)$ & $2(1)$ \\
\hline Eben-Emael & - & - & 2(1) & 2(1) \\
\hline Eprave & - & $2(2)$ & - & $2(2)$ \\
\hline Hoogstraten & - & $16(3)$ & - & $16(3)$ \\
\hline Koninksem & - & $1(1)$ & $2(1)$ & $3(2)$ \\
\hline Leopoldsburg & - & $1(1)$ & $6(1)$ & $7(2)$ \\
\hline Loenhout & - & - & $6(1)$ & $6(1)$ \\
\hline Olloy-sur-Viroin & - & $3(1)$ & - & $3(1)$ \\
\hline St.-Pieters Voeren & - & $4(2)$ & - & $4(2)$ \\
\hline Turnhout & - & 11(1) & - & 11(1) \\
\hline Vielsalm & - & $5(1)$ & $3\left({ }^{*}\right)$ & $8(2)$ \\
\hline \multicolumn{5}{|l|}{ Great Britain } \\
\hline Bolton, W. Yorkshire & - & $2(1)$ & $1(1)$ & $3(2)$ \\
\hline Catrigg Force, Standforth & $8(2)$ & $1(1)$ & - & $9(3)$ \\
\hline Muker, River Swale & - & $3(2)$ & - & $3(2)$ \\
\hline South Croydon, Surrey & - & 1(1) & $14(1)$ & $15(2)$ \\
\hline \multicolumn{5}{|l|}{ Norway } \\
\hline Fleslandsvika, Bergen & $7(1)$ & - & - & $7(1)$ \\
\hline \multicolumn{5}{|l|}{ Sweden } \\
\hline Göteborg, NHM & $18(3)$ & - & - & $18(3)$ \\
\hline Göteborg, Annedal church & $2(1)$ & - & - & $2(1)$ \\
\hline Göteborg, Vitsippsdalen & $7(1)$ & - & $12(1)$ & $19(2)$ \\
\hline Hven & $9(1)$ & - & - & $9(1)$ \\
\hline \multicolumn{5}{|l|}{ The Netherlands } \\
\hline Sirjansland & - & $2(2)$ & - & $2(2)$ \\
\hline
\end{tabular}

Localities at which only single specimens were collected: $A$. fasciatus: Great Britain - Gisburn, W. Yorkshire; A. silvaticus: Austria - Oischevtormäuer; Belgium - Blanden; Dinant, Celles; Rijkhoven; Schilde; Schoten; Stekene; Wellin; A. circumscriptus: Belgium - Erezée; Lomprez; The Netherlands Vlieland.

A. circumscriptus from Vielsalm comprised two Mdh heterozygotes and was not interpreted in terms of strains, as indicated by $\left({ }^{*}\right)$.

(1937) and Waldén (1955). In case of doubt the esterase and albumen gland protein zymograms described by Backeljau et al. (1987) were considered decisive. Specimens were collected at the localities listed in Table 1. In each case sampling sites consisted of only a few square metres.

PAGE procedures and sample preparation of individual digestive gland homogenates followed
Backeljau (1987). A continuous Tris/Citric acid (pH 8.0) buffer was used to resolve malate dehydrogenase (Mdh, EC 1.1.1.37), isocitrate dehydrogenase (Idh, EC 1.1.1.42), phosphogluconate dehydrogenase (Pgdh, EC 1.1.1.44), alanine aminotransferase (Alat, EC 2.6.1.2), esterase Q (EsQ, EC 3.1.1.1 see Backeljau et al., 1987), fumarate hydratase (Fumh, EC 4.2.1.2) and glucose-6-phosphate isomerase ( $\mathrm{Gpi}$, 
EC 5.3.1.9). A discontinuous buffer combination consisting of Tris/ $\mathrm{HCl}(\mathrm{pH} \mathrm{9.0)}$ in the gel and Tris/ Glycine ( $\mathrm{pH} 9.0)$ in the tray, was used to resolve glycerol-3-phosphate dehydrogenase (G3pdh, EC 1.1.1.8), lactate dehydrogenase ( $L d h, \mathrm{EC} 1.1 .1 .27)$, glucose 1-dehydrogenase ( $G c d h, \mathrm{EC} 1.1 .1 .47)$, dihydrolipoamide dehydrogenase ( $D d h$, EC 1.8.1.4), superoxide dismutase (Sod, EC 1.15.1.1), aspartate aminotransferase (Aat, EC 2.6.1.1), phosphoglucomutase (Pgm, EC 5.4.2.2), $\alpha$-amylase (Amy, EC 3.2.1.1.) and leucylalanine aminopeptidase (Pep, EC 3.4.11). Staining recipes were adapted from Harris \& Hopkinson (1976).

Electromorph terminology was based on the mobility $\left(r_{\mathrm{m}}\right)$ of the gene products relative to the fastest electromorph $\left(r_{\mathrm{m}}=100\right)$. We assumed an allelic basis for the observed enzyme profiles and used the Biosys package (Swofford \& Selander, 1981) for estimating allele frequencies, percentages of polymorphic loci ( $P, 0.99$ criterion), Nei's (1978) unbiased expected heterozygosities $\left(H_{\mathrm{e}}\right)$ and Nei's (1972) genetic identities $(I)$ and distances $(D)$. Observed heterozygosities $\left(H_{\mathrm{o}}\right)$ were determined by direct count. Heterozygote deviations $\left(D_{\mathrm{H}}\right)$ were calculated as $D_{\mathrm{H}}=\left(H_{\mathrm{o}}-H_{\mathrm{e}}\right) / H_{\mathrm{e}}$ and averaged over loci. Genetic distances were subjected to UPGMA clustering with the DISPAN (v. 1.1) package (Ota, 1993), which was also used to test the stability of the UPGMA tree by bootstrapping over 1000 replicates.

\section{Results}

Eighteen putative enzyme loci were resolved, 10 of which were fixed for the same allele in the three species, whereas eight were polymorphic over Carinarion as a whole $(P=0.44$; Table 2$)$. Some of these latter loci were also polymorphic within species (and populations), yielding positive $H_{\mathrm{e}}$ values (Table 2). No heterozygotes were observed, however, except for two specimens of $A$. circumscriptus from Vielsalm, Belgium, which were heterozygous at $M d h$. Hence, overall heterozygote deviations were extremely negative (Table 2 ).

In the near absence of heterozygotes, 17 homozygous multilocus genotypes (strains) could be distinguished: three in $A$. fasciatus (A-C), 12 in $A$. silvaticus (D-O) and two in $A$. circumscriptus $(\mathrm{P}-\mathrm{Q})$ (Table 2). Obviously, more strains would be expected if additional loci were screened, i.e. probably every strain defined in this study is in turn a complex of monomorphic lineages.

Considering only populations with at least two specimens, nine out of $14 \mathrm{~A}$. silvaticus (64 per cent), two out of $\operatorname{six} A$. fasciatus ( 33 per cent), but only one out of $11 \mathrm{~A}$. circumscriptus (9 per cent) yielded at least two different strains (Table 1).

Strains of different species co-occurred at 11 sites (Table 1). Thus, 19 of the 28 localities where more than one Carinarion specimen was collected ( 68 per cent), yielded two or more strains (irrespective of the species) (Table 1). At most sites with mixed species (seven of 11), we found one strain per species. But, in two localities ('Antwerpen, RUCA Plein' and 'Catrigg Force, Standforth'), one species was represented by two strains, and in a third locality ('Antwerpen, 't Half Maantje') we observed three $A$. silvaticus and two $A$. circumscriptus strains (Table 1 ). The remaining site with mixed species ('Vielsalm') was unique because of two $A$. circumscriptus specimens with presumed heterozygous $M d h^{100} / M d h^{86}$ genotypes.

Table 3 summarizes the genetic identities and distances between strains, resulting in a mean interstrain identity of $I=0.81$. The UPGMA tree of the 17 strains clustered conspecific strains together, even though bootstrap values were very low (Fig. 1). Nevertheless, there was a strong support for a sister group relationship between $A$. fasciatus and $A$. silvaticus.

\section{Discussion}

Contrary to previous studies by McCracken \& Selander (1980), Foltz et al. (1982), Selander \& Ochman (1983) and Dolan \& Fleming (1988), our work clearly shows that the three Carinarion spp. are polymorphic, multistrain complexes, instead of single monomorphic lines. This is surprising for the literature data on $A$. fasciatus and $A$. circumscriptus were based on considerably larger numbers of specimens and comparable numbers of populations. McCracken \& Selander (1980), for example, surveyed 10 populations of $A$. fasciatus in North America (814 specimens) and the same authors, together with Foltz et al. (1982) and Dolan \& Fleming (1988), investigated 362 specimens (respectively, 312, 46 and four) from 10 populations (respectively, four, five and one) of $A$. circumscriptus. Only for $A$. silvaticus were the earlier data of McCracken \& Selander (1980) and Foltz et al. (1982) based on a smaller total sample size, i.e. 77 specimens (29 and 48) from seven populations (respectively, three and four). However, as we found no significant correlation between the number of strains detected and the number of specimens screened per population in $A$. silvaticus ( $r=0.124, N_{\text {obs. }}=14, P=0.67$ ), we assume that sampling bias may be of little, if any, importance. 


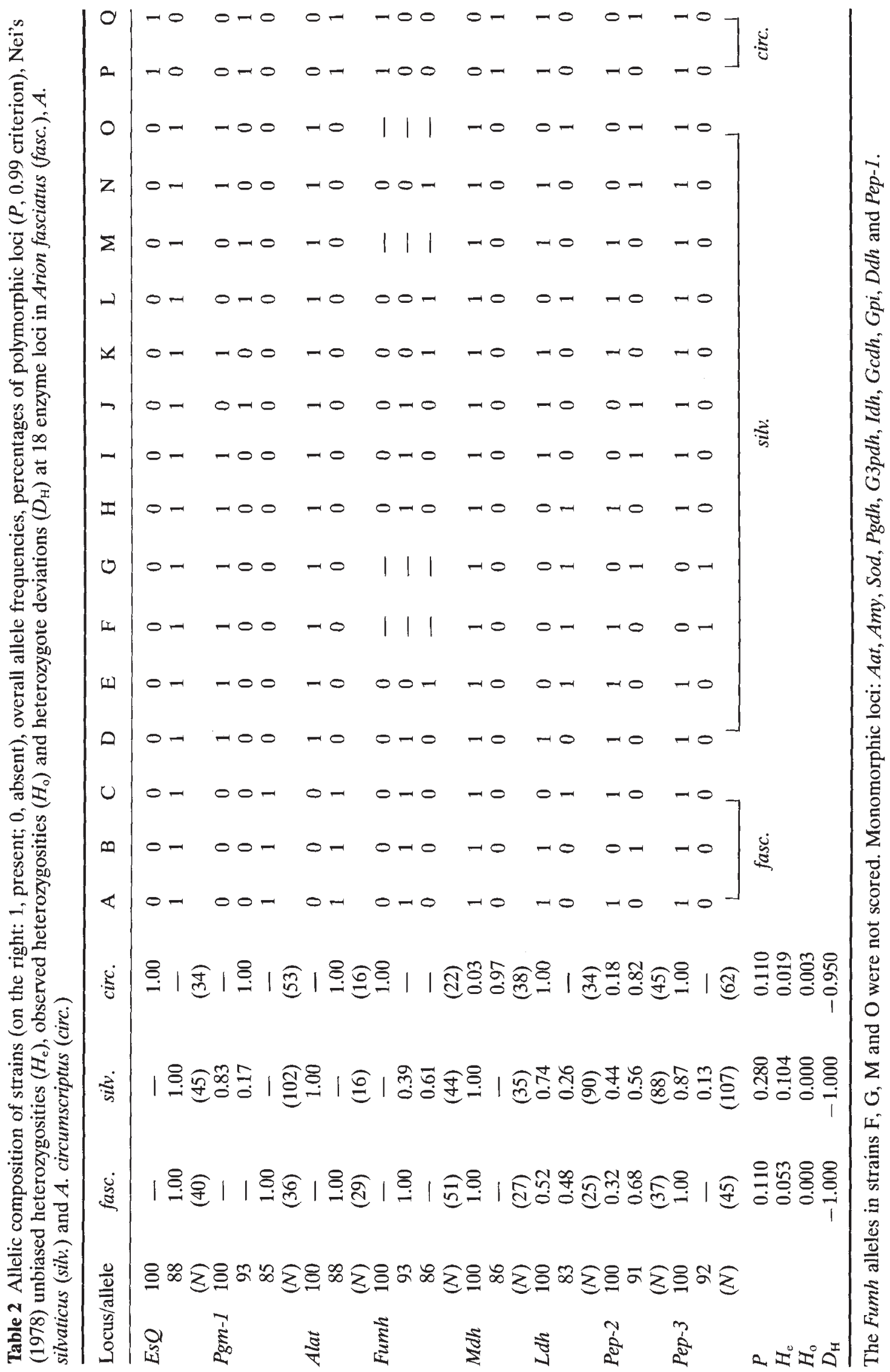


Table 3 Mean Nei's (1972) genetic identities $\left(I_{\text {av }}\right)$ and distances $\left(D_{\mathrm{av}}\right)$, between 17 Carinarion strains at different levels of comparison

\begin{tabular}{lcccccr}
\hline Comparisons & $D_{\mathrm{av}} \pm \mathrm{SD}$ & Min. & Max. & $I_{\mathrm{av}} \pm \mathrm{SD}$ & Min. & Max. \\
\hline All strains & $0.22 \pm 0.12$ & 0.06 & 0.59 & $0.81 \pm 0.10$ & 0.56 & 0.94 \\
Intra A. fasciatus (f) & $0.08 \pm 0.04$ & 0.06 & 0.12 & $0.93 \pm 0.03$ & 0.89 & 0.94 \\
Intra . silvaticus (s) & $0.14 \pm 0.06$ & 0.06 & 0.33 & $0.87 \pm 0.05$ & 0.72 & 0.94 \\
Intra A. circumscriptus $(\mathrm{c})$ & 0.06 & - & - & 0.94 & - & - \\
Inter f/s & $0.24 \pm 0.08$ & 0.12 & 0.41 & $0.79 \pm 0.06$ & 0.67 & 0.89 \\
Inter f/c & $0.31 \pm 0.06$ & 0.25 & 0.41 & $0.73 \pm 0.04$ & 0.67 & 0.78 \\
Inter c/s & $0.40 \pm 0.09$ & 0.25 & 0.59 & $0.67 \pm 0.06$ & 0.56 & 0.78 \\
\hline
\end{tabular}

Values for the strains F, G, M and O were calculated by assuming that they were fixed for $F u m h^{86}$; $M d h$ heterozygotes were not considered.

Fig. 1 UPGMA tree of Nei's (1972) genetic distances between 17 Carinarion strains: $A$. fasciatus (A-C), $A$. silvaticus (D-O) and $A$. circumscriptus $(\mathrm{P}-\mathrm{Q})$. Numbers at the nodes are bootstrap percentages based on 1000 replicates.

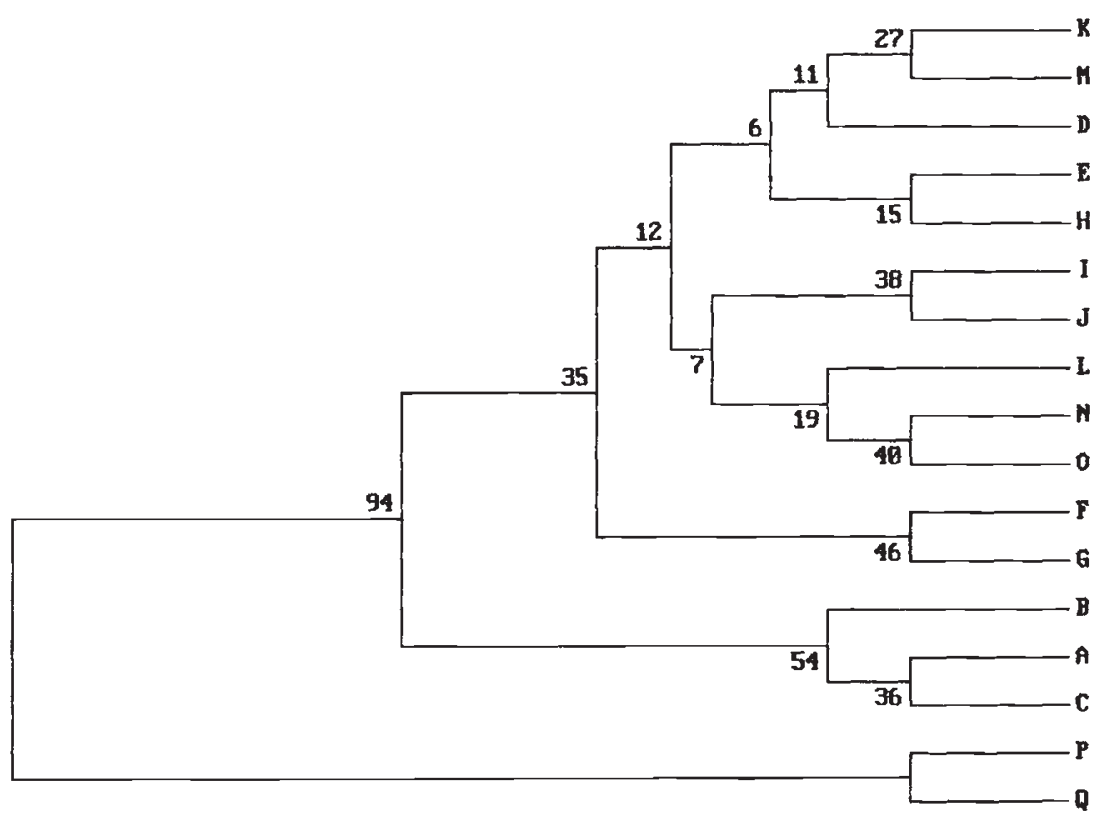

Two other artefacts might explain why previous studies did not detect variation: bias in the choice of enzymes and differences in the resolving power of electrophoretic techniques (e.g. Coyne et al., 1979). However, we included four variable enzymes that were also screened by previous authors (EsQ, Pgm, $M d h$ and Pep) and these enzymes still allow the detection of ten strains (two in $A$. fasciatus, two in $A$. circumscriptus and six in $A$. silvaticus). Nevertheless, McCracken \& Selander (1980) and Foltz et al. (1982) found with starch gel electrophoresis (SGE) only one monomorphic locus for leucylalanine aminopeptidase (their Pep-1; R.K. Selander in litt., 1986), whereas with PAGE this enzyme yielded at least two polymorphic loci (Table 2). Similarly, using SGE Dolan \& Fleming (1988) were unable to separate the Pgm and Sod alleles of $A$. circumscrip- tus from those of other arionids, whereas Backeljau \& De Winter (1987) showed with PAGE that these alleles are not shared between Carinarion and other arionids. On the other hand, SGE detected the $\mathrm{Pgm}^{\mathrm{b}}$ allele (Foltz et al., 1982), which cannot be homologized with the Pgm alleles we found, even if we assume that $\mathrm{Pgm}^{\text {a }}$ is our Pgm-1 ${ }^{100}$ and $\mathrm{Pgm}^{\mathrm{c}}$ is our Pgm-1 $1^{93}$ (compare our Table 2 with table 5 of Foltz et al., 1982).

Without further experimentation we cannot decide whether the lack of genetic variation in north American Carinarion (McCracken \& Selander, 1980) is artifactual. Nevertheless, our data unequivocally show that at least in Europe the three species are polymorphic and may produce heterozygotes. The generally accepted idea that the single strain structure of American Carinarion populations is not the 
result of a loss of genetic variation caused by their introduction from more variable European populations (Selander \& Ochman, 1983; Foltz et al., 1984), should therefore be readdressed. In this context it is noteworthy also that of the selfing Mediterranean land snail, Rumina decollata, only one out of many European strains was introduced into the U.S.A., where it is now widespread (Selander \& Kaufman, 1973).

Our data further confirm that Carinarion mainly reproduces uniparentally (e.g. McCracken \& Selander, 1980; Foltz et al., 1982, 1984; Backeljau et al., 1987), for this seems the most parsimonious explanation for the rarity of heterozygotes in widely distributed, polymorphic populations (e.g. Foltz et al., 1982, 1984; Selander \& Ochman, 1983). Yet, whether this uniparental breeding system involves autogamy, automixis or apomixis (sensu Mogie, 1986), remains to be decided (e.g. Nicklas \& Hoffmann, 1981; Hoffmann, 1983; Selander \& Ochman, 1983; Foltz et al., 1984; Tompa, 1984; Backeljau \& De Bruyn, 1991). Anyhow, the two $M d h$-heterozygotes in $A$. circumscriptus suggest that outcrossing is possible in natural populations, even though it is unclear how often and under what conditions it may occur. This issue, and the estimation of selfing rates, can only be addressed appropriately with breeding experiments using known genetic markers (Jarne \& Charlesworth, 1993; Jarne \& Städler, 1995). Indeed, it may be questioned whether uniparental reproduction is the main breeding system over the entire range of Carinarion, for preliminary data from East European populations suggest that in these regions outcrossing may be more common (K. Jordaens, $\mathrm{T}$. Backeljau and H. De Wolf, unpublished data).

The high incidence of multistrain populations in $A$. silvaticus (64 per cent) and $A$. fasciatus (33 per cent) seems at variance with the predictions of Selander \& Ochman (1983), who modelled interactions between self-compatible strains of terrestrial pulmonates. This model states that slight fecundity differences between strains may lead to the eventual elimination of the less fecund ones. Therefore, most local populations of mainly, but not exclusively, selfing multistrain species would consist of single strains (Selander \& Ochman, 1983). Consequently, this model does not seem directly applicable to $A$. silvaticus and $A$. fasciatus. Nevertheless, it remains possible that co-occurring Carinarion strains also interact competitively or are eco-ethologically differentiated in other traits. Furthermore, it is unknown whether multistrain populations are stable in time.

In conclusion, our data suggest that earlier population genetic surveys of Carinarion were not suffi- ciently representative either because of artifactual issues or (and?) because of a true lack of variation in American populations. This implies that the conclusions of McCracken \& Selander (1980) as to the species status of $A$. fasciatus, $A$. circumscriptus and $A$. silvaticus also need to be re-evaluated. Although it is beyond the scope of this paper to expand on this issue, we find it suggestive that: (i) many other terrestrial pulmonates, such as Rumina decollata, Chondrina clienta, $A$. intermedius, $A$. subfuscus and the Cochlicopa complex are multistrain taxa that often consist of several 'discrete' morphotypes based on colour, size and shell form (e.g. Selander \& Kaufman, 1973; Selander \& Hudson, 1976; McCracken \& Selander, 1980; Baur \& Klemm, 1989; Backeljau \& De Bruyn, 1991; Backeljau et al., 1992; Armbruster \& Schlegel, 1994); (ii) the mean genetic identity between Carinarion strains $(I=0.81)$ is comparable to that of conspecific strains in Chondrina clienta $(I=0.81$; Baur \& Klemm, 1989) or A. intermedius ( $I=0.87$; McCracken \& Selander, 1980); and (iii) the separation of $A$. silvaticus and $A$. fasciatus in the tree of Fig. 1 disappears when East European material is included (K. Jordaens, T. Backeljau \& H. De Wolf, unpublished data). Therefore, we currently speculate that Carinarion might very well represent a single 'species', which because of its mainly uniparental breeding system is divided into a series of morphotypes and genetic strains.

\section{Acknowledgements}

We thank S. M. Davies, C. Frank, A. Norris, T. Solhöy and T. von Proschwitz for providing us with part of the specimens. The comments by H. Reise, J.L. Van Goethem, K. Wouters and two anonymous referees improved the manuscript considerably. H.D.W. and B.W. have an I.W.T. fellowship. L.D.B. and S.V.D. are at the N.F.S.R. (Belgium). This work was supported by F.J.B.R. grants 2.0004.91, 2.0023.94 and 2.0128.94.

\section{References}

ARMBruster, G. AND SCHLEGEL, M. 1994. The land-snail species of Cochlicopa (Gastropoda: Pulmonata: Cochlicopidae): presentation of taxon-specific allozyme patterns, and evidence for a high level of self-fertilization. J. Zool. Syst. Evol. Res., 32, 282-296.

BACKELJAU, T. 1987. Electrophoretic distinction between Arion hortensis, $A$. distinctus and $A$. owenii (Mollusca: Pulmonata). Zool. Anz., 219, 33-39.

BACKelJau, T. AND DE BRUYN, L. 1991. Preliminary report on the genetic variability of Arion intermedius in Europe

(c) The Genetical Society of Great Britain, Heredity, 78, 445-451. 
(Pulmonata). J. Med. Appl. Malacol., 3, 19-29.

BACKELJAU, T. AND DE WINTER, A. J. 1987. An electrophoretic characterisation of three paratypes of Arion fagophilus De Winter, 1986, with notes on the subgeneric division of the genus Arion Férussac, 1819 (Mollusca, Pulmonata). Z. Zool. Syst. Evolut.-forsch., 25, 169-180.

BACKELJAU, T., AHMADYAR, S. Z., SELENS, M., VAN ROMPAEY, J. AND VERHEYEN, w. 1987. Comparative electrophoretic analyses of three European Carinarion species (Mollusca, Pulmonata, Arionidae). Zool. Scr., 16, 209-222.

BACKELJAU, T., DE BRITO, C. P., TRISTÃo DA CUNHA, R. M., FRIAS MARTINS, A. M. AND DE BRUYN, L. 1992. Colour polymorphism and genetic strains in Arion intermedius from Flores, Azores (Mollusca: Pulmonata). Biol. J. Linn. Soc., 46, 131-143.

BAUR, B. AND KLEMM, M. 1989. Absence of isozyme variation in geographically isolated populations of the land snail Chondrina clienta. Heredity, 63, 239-244.

CHICHESTER, L. F. AND GETZ, L. L. 1969. The zoogeography and ecology of arionid and limacid slugs introduced into northeastern North America. Malacologia, 7, 313-346.

COYNE, J. A., EANES, W. F., RAMSHAW, J. A. M. AND KOEHN, R. K. 1979. Electrophoretic heterogeneity of $\alpha$-glycerophosphate dehydrogenase among many species of Drosophila. Syst. Zool., 28, 164-175.

DOLAN, S. AND FLEMING, c. C. 1988. Isoenzymes in the identification and systematics of terrestrial slugs of the Arion hortensis complex. Biochem. Syst. Ecol., 16, 195-198.

FOLTZ, D. W., OCHMAN, H., JONES, J. S., EVANGELISTI, S. M. AND SELANDER, R. K. 1982. Genetic population structure and breeding systems in arionid slugs (Mollusca: Pulmonata). Biol. J. Linn. Soc., 17, 225-241.

FOLTZ, D. W., OCHMAN, H. AND SELANDER, R. K. 1984. Genetic diversity and breeding systems in terrestrial slugs of the families Limacidae and Arionidae. Malacologia, 25, 593-605.

HARRIS, H. AND HOPKINSON, D. A. 1976. Handbook of Enzyme Electrophoresis in Human Genetics. Elsevier/ North Holland Publishing Company, Amsterdam.

HOFFMANN, R. J. 1983. The mating system of the terrestrial slug Deroceras laeve. Evolution, 37, 423-425.

JARNE, P. AND CHARLESWORTH, D. 1993. The evolution of the selfing rate in functionally hermaphrodite plants and animals. Ann. Rev. Ecol. Syst., 24, 441-466.

JARNE, P. AND STÄDLER, T. 1995. Population genetic struc- ture and mating system evolution in freshwater pulmonates. Experientia, 51, 482-497.

KERNEY, M. P., CAMERON, R. A. D. AND JUNGBLUTH, J. H. 1983. Die Landschnecken Nord- und Mitteleuropas. Paul Parey, Hamburg.

LOHMANDER, H. 1937. Ueber die nordischen Formen von Arion circumscriptus Johnston. Acta Soc. Fauna Flora Fenn., 60, 90-112.

MCCRACKEN, G. F. AND SELANDER, R. K. 1980. Self-fertilization and monogenic strains in natural populations of terrestrial slugs. Proc. Natl. Acad. Sci. U.S.A., 77, 684-688.

MOGIE, M. 1986. Automixis: its distribution and status. Biol. J. Linn. Soc., 28, 321-329.

NEI, M. 1972. Genetic distance between populations. Am. Nat., 106, 283-292.

NEI, M. 1978. Estimation of average heterozygosity and genetic distance from a small number of individuals. Genetics, 89, 583-590.

NICKLAS, N. L. AND HOFFMANN, R. J. 1981. Apomictic parthenogenesis in a hermaphroditic terrestrial slug, Deroceras laeve (Müller). Biol. Bull., 160, 123-135.

OTA, T. 1993. DISPAN: Genetic distance and phylogenetic analysis, version 1.1. Pennsylvania State University, University Park, PA.

SELANDER, R. K. AND HUDSON, R. O. 1976. Animal population structure under close inbreeding: the land snail Rumina in southern France. Am. Nat., 110, 695-718.

SELANDER, R. K. AND KAUfMAN, D. w. 1973. Self-fertilization and genetic population structure in a colonizing land snail. Proc. Natl. Acad. Sci. U.S.A., 70, 1186-1190.

SELANDER, R. K. AND OCHMAN, H. 1983. The genetic structure of populations as illustrated by molluscs. In: Rattazzi, M. C., Scandalios, J. C. Z. and Whitt, G. S. (eds) Isozymes: Current Topics in Biological and Medical Research, vol. 10: Genetics and Evolution, pp. 93-123. Alan R. Liss, New York.

SWOFFORD, D. L. AND SELANDER, R. B. 1981. BIOSYS-1: A FORTRAN program for the comprehensive analysis of electrophoretic data in population genetics and systematics. J. Hered., 72, 281-283.

томРA, А. s. 1984. Land snails (Stylommatophora). In: Tompa, A. S., Verdonk, N. H. and Van Den Biggelaar, J. A. M. (eds) The Mollusca, vol. 7, Reproduction, pp. 47-140. Academic Press, Orlando, FL.

WALDÉN, H. W. 1955. The land Gastropoda of the vicinity of Stockholm. Ark. Zool., 7, 391-448. 